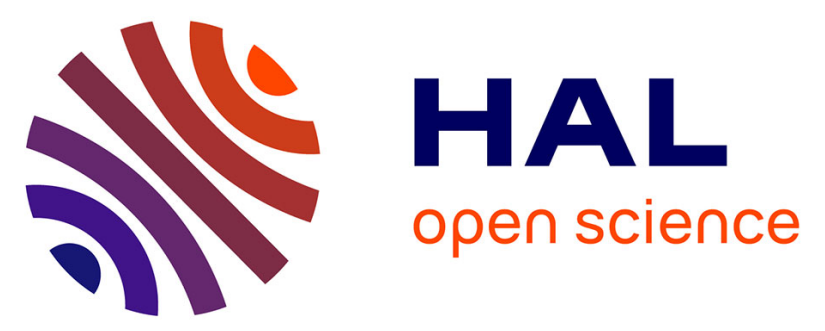

\title{
The effects of $\mathrm{N}$-enriched rain and warmer soil on the ectomycorrhizae of black spruce remain inconclusive in the short term
}

Sergio Rossi, Adam Bordeleau, Hubert Morin, Daniel Houle

\section{- To cite this version:}

Sergio Rossi, Adam Bordeleau, Hubert Morin, Daniel Houle. The effects of N-enriched rain and warmer soil on the ectomycorrhizae of black spruce remain inconclusive in the short term. Annals of Forest Science, 2013, 70 (8), pp.825-834. 10.1007/s13595-013-0329-1 . hal-01201527

\author{
HAL Id: hal-01201527 \\ https://hal.science/hal-01201527
}

Submitted on 17 Sep 2015

HAL is a multi-disciplinary open access archive for the deposit and dissemination of scientific research documents, whether they are published or not. The documents may come from teaching and research institutions in France or abroad, or from public or private research centers.
L'archive ouverte pluridisciplinaire HAL, est destinée au dépôt et à la diffusion de documents scientifiques de niveau recherche, publiés ou non, émanant des établissements d'enseignement et de recherche français ou étrangers, des laboratoires publics ou privés. 


\title{
The effects of $\mathbf{N}$-enriched rain and warmer soil on the ectomycorrhizae of black spruce remain inconclusive in the short term
}

\author{
Sergio Rossi • Adam Bordeleau • Hubert Morin • \\ Daniel Houle
}

Received: 12 April 2013 / Accepted: 2 September 2013 / Published online: 27 September 2013

(C) INRA and Springer-Verlag France 2013

\begin{abstract}
- Context Warmer temperatures and anthropogenic N depositions are altering soil nutrient cycles and plant nutrition worldwide and are projected to rise dramatically in the future, particularly at the high latitudes. How much will such alterations affect symbiotic organisms such as ectomycorrhizae (ECM)?

- Aims The aim was to investigate the short-term effects of warmer soil temperatures and $\mathrm{N}$-enriched precipitations on roots and ECM.

- Methods A field experiment was established during 20082010 in two black spruce (Picea mariana) stands of the boreal forest of Quebec, Canada. The ECM of 12 trees per site were counted and identified by morphotyping.

- Results After 3 years, soil heating markedly modified the proportions of vital root tips and ECM in the colder stand, while no effect of the $\mathrm{N}$-enriched rain was observed on soil
\end{abstract}

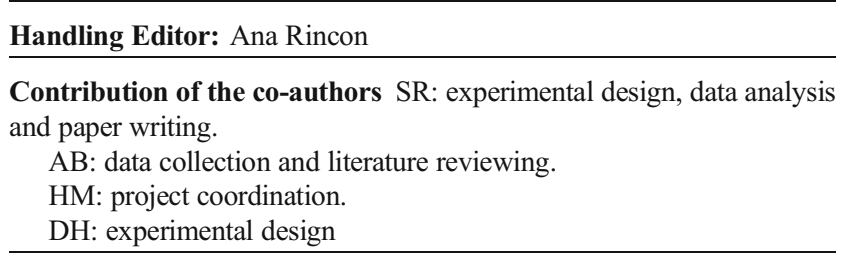

S. Rossi $(\bowtie) \cdot$ A. Bordeleau $\cdot$ H. Morin

Département des Sciences Fondamentales, Université du Québec à

Chicoutimi, 555 Boulevard de l'Université, Chicoutimi, QC,

Canada G7H2B1

e-mail: sergio.rossi@uqac.ca

D. Houle

Direction de la Recherche Forestière, Forêt Québec, Ministère des Ressources naturelles et de la Faune, 2700 rue Einstein, Sainte-Foy, Québec, QC, Canada G1P 3W8

D. Houle

Ouranos, 550 Sherbrooke Ouest, Tour Ouest, 19ième étage,

Montréal, QC, Canada H3A1B9 chemistry and consequently on roots and ECM. Density and ramification of root tips were not affected by the treatments.

- Conclusion The hypothesis that the treatments would alter the ECM was confirmed only partially in the colder stand. The type of application and amount of $\mathrm{N}$ supplied were unable to substantially modify in the short-term growth conditions of roots and ECM, explaining the observed results.

Keywords Boreal forest $\cdot$ Nitrogen $\cdot$ Fungal diversity Morphotyping $\cdot$ Picea mariana $\cdot$ Soil temperature

\section{Introduction}

In the boreal forest, the reduced evapotranspiration and low decomposition rates slow down the nutrient cycle and lead to a gradual accumulation of organic matter during forest stand successions, maintaining a huge part of the nitrogen in the ecosystem in a form unavailable for plants (Read et al. 2004; Rossi et al. 2009). The climatic models for Northeastern Canada estimate a warming of up to $3{ }^{\circ} \mathrm{C}$ over the next 50 years (Plummer et al. 2006), with effects already noticeable in the growth dynamics of the boreal species (Boulouf Lugo et al. 2012). The increase in surface air temperature and the changes in the dates of snowmelt will inevitably warm the soil, with expected increases during the growing season of $4{ }^{\circ} \mathrm{C}$ for $2050-2100$ (Houle et al. 2012). Along with the increased anthropogenic $\mathrm{N}$ depositions, soil warming is expected to increase decomposition, thus favoring mineralization and enhancing $\mathrm{N}$ availability (Campbell et al. 2009). This may alter the slow nutrient cycles and, potentially, the dynamics of all living organisms in the soil. As the boreal forest represents $27 \%$ of the world's forest cover and contains more than $30 \%$ of all carbon present in the terrestrial biomes (Kasischke 2000), any change in this biome has obvious 
ecological and economic relevance and should be predicted as soon as possible.

Investigations on increased nutrient availability have used large amounts of $\mathrm{N}$, often spread in few applications directly on the forest floor, which can hardly be compared to a natural process (Gundale et al. 2011). On the contrary, most of the boreal region receives only $4 \mathrm{~kg} \mathrm{ha}^{-1} \mathrm{year}^{-1}$ or less of nitrogen, while past studies have added quantities of 1-3 orders of magnitude higher, representing a fertilization rather than a natural deposition (Gundale et al. 2011). In the past, warming of trees was regularly performed on seedlings in a growth chamber or nursery (Domisch et al. 2002), which precluded the possibility of extending the results to the whole stand. More recently, warming has been more suitably carried out in the field, with the challenging technical problems related to works in natural and remote locations (Clemmensen et al. 2006).

In 2008, a field experiment was established in two mature stands of the boreal forest of Quebec, Canada, simulating increases in soil temperature and nitrogen-enriched rainfall (Lupi et al. 2012a). After only 3 years of treatment, the effects on trees were slight but significant. In particular, the major findings concerned the phenology of roots, which showed earlier resumptions and longer durations of growth in warmed soils (Lupi et al. 2012a). The root system of trees is a resource for which a number of symbionts compete, and root colonisation is a necessary condition for survival and reproduction of mycorrhizal fungi (Bruns 1995). Besides, boreal forest conifers allocate high proportions of their photosynthates for the metabolism of belowground organs to feed and sustain as wide as possible a variety of ectomycorrhizae (ECM) (Read et al. 2004). In turn, ECM proliferate within the organic horizons where they intensely exploit the $\mathrm{N}$ stored within the litter and in the organic matter for improving plant nutrition. Thus, ECM fungi and communities are expected to be markedly affected by alterations of soil. Moreover, ECM are the more dynamic components of the partnership and respond directly and more rapidly to environmental disturbances and climate change than their long-living hosts (Staddon et al. 2002, Deslippe et al. 2011).

Because of their central role in several biogeochemical processes of the ecosystem, any modification of the ECM may generate feedbacks on other components of the system, such as the soil or the vegetal partner. In addition to nutrient uptake, ECM symbioses improve the protection from soil pathogens and the tolerance to stress of trees. Consequently, any environmental disturbance could affect plants directly, via modifications of the growing conditions, and indirectly, by modifying the nature and abundance of mycorrhizae. Fine roots growing in warmer soils or at higher $\mathrm{N}$ availability are expected to experience increased ECM colonisations (Rossi et al. 2012) because of the higher species richness and mycelial growth (Clemmensen et al. 2006; Kranabetter et al. 2009). However, Lilleskov et al. (2008) observed contrasting and species-specific responses of ECM, with the frequency of certain morphotypes either increasing or decreasing with $\mathrm{N}$ availability. This paper investigated the ECM 3 years after the beginning of the experiment by Lupi et al. (2012b). We expected that the longer growing periods observed in certain treatments may correspond to modifications of the relationships of host-symbionts and, consequently, to changes in the presence of ECM. A hypothesis was proposed that soil heating and nitrogen addition by simulated rain would rapidly and substantially alter the ECM both in terms of presence and diversity of species. The hypothesis was tested by comparing ECM abundance and richness between the treatments. Root tip vitality was also analysed in order to quantify the eventual effects of the treatments on the absorbing parts of the root system.

\section{Material and methods}

\subsection{Study sites}

The study was conducted in two mature, even-aged and monospecific black spruce [Picea mariana (Mill.) BSP] stands of the boreal forest of Quebec, Canada. The first site (abbreviated as BER) was located near lake Bernatchez, in the Monts-Valin ( $48^{\circ} 51^{\prime} \mathrm{N}, 70^{\circ} 20^{\prime} \mathrm{W}, 611 \mathrm{~m}$ a.s.l.). The second site (SIM) was at a lower altitude, in the réserve faunique des Laurentides, within the Simoncouche research station $\left(48^{\circ} 13^{\prime}\right.$ $\mathrm{N}, 71^{\circ} 15^{\prime} \mathrm{W}, 350 \mathrm{~m}$ a.s.1.). The stands are growing on gentle slopes $(8-17 \%)$ and drained glacial tills. They originate from forest fires that occurred in 1870 and 1922 for BER and SIM, respectively. The climate is continental, with short summers and long, cold winters with mean annual temperatures of 0.2 and $1.9^{\circ} \mathrm{C}$ for BER and SIM, respectively, and a total MaySeptember rainfall of $413.6 \mathrm{~mm}$ (Lupi et al. 2010, Boulouf Lugo et al. 2012). Snow cover lasts from November to May, reaching a depth of up to $150 \mathrm{~cm}$ in both sites. Because of its higher altitude and latitude and shorter snow-free periods, trees in BER experience shorter growing seasons and grow in more humid and cold soils than those in SIM (Rossi et al. 2011b). According to Boulouf Lugo et al. (2012), during 2002-2010, the average growing season was 125 and 109 days in SIM and BER, respectively. The soils of both sites were podzol with a mor-type humus (Table 1). The LFH (organic) horizon was 10 and $18 \mathrm{~cm}$ in depth in SIM and BER, respectively. In SIM, the maximum rooting depth was frequently limited by a shallow bedrock.

\subsection{Experimental design}

In each site, a square plot of $60 \times 60 \mathrm{~m}$ was delimited and divided in twenty-five $12 \times 12$-m squares, of which 12 acted as experimental units with the others being buffer zones (Fig. 1). 
Table 1 Soil description of the two studied sites

\begin{tabular}{lll}
\hline & BER & SIM \\
\hline Soil type & Podzol & Podzol \\
Humus type & Mor & Mor \\
& Of, $0-11 \mathrm{~cm}$ & Of, 0-2 cm \\
& Om, $11-16 \mathrm{~cm}$ & Om, $2-8 \mathrm{~cm}$ \\
Profile description & Oh, 16-18 cm & Oh, 8-10 cm \\
& Ae, $18-23 \mathrm{~cm}$ & Ae, $10-26 \mathrm{~cm}$ \\
& Bhf, $23-26 \mathrm{~cm}$ & Bf, $26-45 \mathrm{~cm}$ \\
& B, 26-46 cm & C, $>45 \mathrm{~cm}$ \\
& C, $>46 \mathrm{~cm}$ & \\
\hline
\end{tabular}

Of organic fibric, $O m$ organic mesic, $O h$ organic humic, Ae surface eluvial horizon, $B$ buried horizon, $B h f$ enriched with organic matter, $\mathrm{Fe}$ and $\mathrm{Al}, B f$ enriched with $\mathrm{Fe}$ and $\mathrm{Al}, C$ cemented horizon

In each experimental unit, a tree was chosen with upright stem and healthy overall appearance. On average, trees were 16 and $17 \mathrm{~m}$ tall, with a diameter at breast height of 17 and $20 \mathrm{~cm}$ in BER and SIM, respectively. Different treatments were applied during 2008-2010, consisting of an increase in soil temperature (heated trees, abbreviated as $\mathrm{H}$ ), a canopy application of artificial rain enriched with nitrogen ( $\mathrm{N}$-enriched trees, $\mathrm{N}$ ) and a combination of heating and $\mathrm{N}$ enrichment (NH trees). The combination of the treatments resulted in three different levels $(\mathrm{H}, \mathrm{N}, \mathrm{NH})$ and a control $(\mathrm{C})$ that were organized in a random split plot design with three replications (Fig. 1).

For the $\mathrm{H}$ treatment, heating cables were installed during the autumn of 2007 between the organic and mineral soil layers, at about $20-30-\mathrm{cm}$ depth, where the root system of black spruce is mainly localized (Ruess et al. 2003), following a spiral pattern at a distance of 90-200 cm from the stem collar. To account for potential root damage and soil disturbance during cable laying, non-heating cables were also installed around control trees. The power unit consisted of a diesel generator located $200 \mathrm{~m}$ from the site, and soil temperature was measured between the coils of the cables for three heated and three control trees. The treatment was carried out in spring, during the period in which most cambial division takes place (Thibeault-Martel et al. 2008; Rossi et al. 2011a), and consisted of increasing the soil temperature by $4{ }^{\circ} \mathrm{C}$ in line with the forecasts for 2100 in the boreal forest of eastern Canada (Houle et al. 2012).

The artificial rain was produced by sprinklers installed above the canopy of each tree. Each week, the equivalent of 2-mm rainfall was applied to the canopy, during the frost-safe period (June to September), for a number of weeks varying between 12 and 16. Rain was applied over a circular area of 3$m$ radius centred on the stem of each experimental tree, which allowed the canopy area to be covered. Control trees were irrigated with a water solution reproducing the chemical composition of natural rainfall over the studied sites (Duchesne and Houle 2008), while for N-enriched treatment, a threefold increase in ammonium nitrate $\left(\mathrm{NH}_{4} \mathrm{NO}_{3}\right)$ concentration was used. Actually, the sites receive naturally $0.7-1 \mathrm{~kg} \mathrm{ha}^{-1}$ year $^{-1}$ of $\mathrm{N}$, while $\mathrm{N}$ trees were supplied with an additional 0.35 $0.5 \mathrm{~kg} \mathrm{ha}^{-1}$ year $^{-1}$ of $\mathrm{N}$, representing approximately an increase of $50 \%$ in $\mathrm{N}$ per year. The treatment with frequent $\mathrm{N}$ additions at low concentration provided directly to the canopy accurately imitated the natural $\mathrm{N}$ depositions expected within 50 years in Quebec.

\subsection{Sampling and data collection}

In October 2010, three soil cores (17 cm in length and $4.5 \mathrm{~cm}$ in diameter) per tree were collected at a distance of $150 \mathrm{~cm}$ from the root collar, sealed in plastic bags, immediately transported to the lab and stored at $-10{ }^{\circ} \mathrm{C}$ in the dark. Cores were collected with a hand auger from the organic horizon, where the majority of black spruce fine root production occurs (Ruess et al. 2003), around the stem to achieve the greatest sampling efficiency for analysis of the ECM (Lilleskov et al. 2004). The analyses were performed within 8 months from sampling. Fifteen root fragments per sample were randomly chosen among those with undamaged and fully developed apical tips and were carefully cleaned in water under a
Fig. 1 Experimental design in BER and SIM with the location of control $(C)$, heated $(H)$ and Nenriched $(N)$ trees. $N H$ corresponds to trees subject to the combined treatment
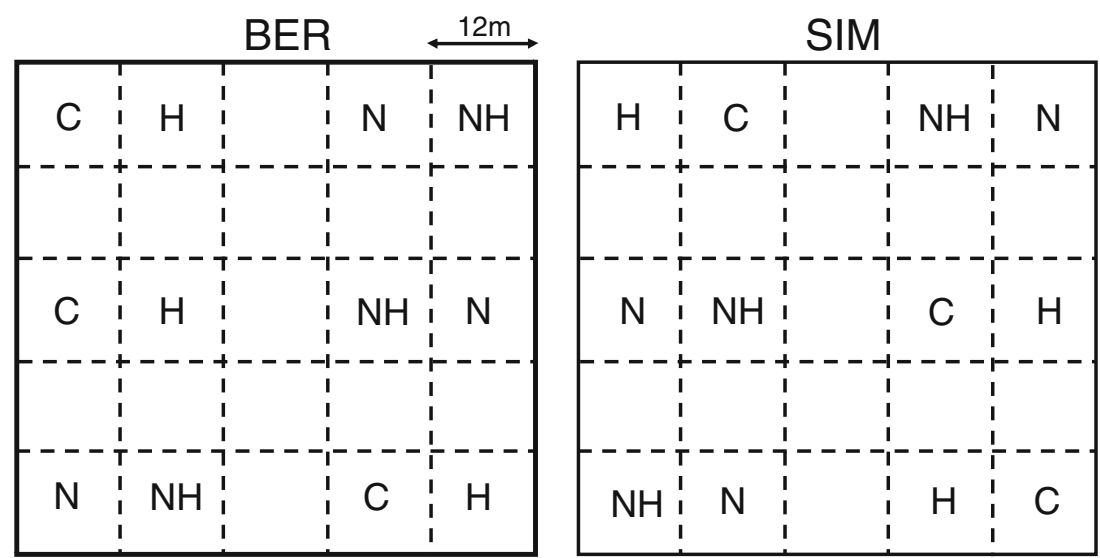
stereomicroscope. Five root tips located at the distal portion of the fragment (i.e. situated away from the point of attachment) and representing the last formed apexes of each rootles were chosen and classified as vital or non-vital according to Montecchio et al. (2004). Preliminary analyses demonstrated that this sampling size was adequate to statistically represent the ECM of black spruce (Rossi et al. 2012). Moreover, the five distal tips allowed to observe the most recently produced tips and consequently those representing the response to the treatments. Non-vital tips showed a scurfy surface and an easily detachable cortex, with or without remnants of ECM mantle. Vital tips were well developed, turgid and inflated. The vital tips were classified as mycorrhized or nonmycorrhized according to whether the ECM mantle was present or lacking, respectively. The systems deriving from ramification of ECM were counted as one ECM, irrespective of the extent of ramification (Montecchio et al. 2004). The rootlet length was defined as the length of the root fragment where the five root tips were collected. The number of root tips and ramifications per unit of rootlet length was calculated for assessing their density along the rootlet. Damaged and not fully developed root tips were excluded from the observations.

All collected ECM were coded and classified into morphotypes by recording their morphological and anatomical characteristics under a stereomicroscope and a light microscope, at magnifications of $\times 40$ and $\times 400$, respectively, using the available literature (Agerer 1991; Goodman et al. 1996; Agerer and Rambold 2004-2011). ECM characteristics included the occurrence and type of ramification, colour and features of the mantle surface and type and features of the outer, middle and inner mantles. Also, when present, type and features of the emanating elements (hyphae, rhizomorphs, cystidia, laticifers) were observed and described in order to identify each morphotype as accurately as possible. The detection of the main microscopic (anatomical) features besides the macroscopic (morphological) characteristics allowed a more reliable and unambiguous identification of the ECM in the different morphotypes (Mehmann et al. 1995).

For assessing element concentration after treatments, soil cores were collected in October 2010, at the end of the 3 years of experiment. Soil was air dried at $65^{\circ} \mathrm{C}$ for $48 \mathrm{~h}$ and sieved through a 2-mm mesh. The amount of total carbon $\left(\mathrm{C}_{\text {tot }}\right)$ and nitrogen $\left(\mathrm{N}_{\text {tot }}\right)$ extracted was determined using a combustion element analyser. Potassium $(\mathrm{K})$, calcium $(\mathrm{Ca})$, magnesium $(\mathrm{Mg})$, manganese $(\mathrm{Mn})$, aluminium $(\mathrm{Al})$, iron $(\mathrm{Fe})$, sodium $(\mathrm{Na})$, sulphur $(\mathrm{S})$ and $\mathrm{pH}$ were determined using an unbuffered ammonium chloride $\left(\mathrm{NH}_{4} \mathrm{Cl} ; 1 \mathrm{~mol} \mathrm{~L}^{-1}, 12 \mathrm{~h}\right.$ ) solutions.

\subsection{Statistics}

Generalised linear mixed models [GLIMMIX procedure in SAS 9.2 (SAS Institute Inc., Cary, NC)] were used for analysing the proportion of vital and mycorrhizal tips. Generalised linear mixed models (GLMMs) were modelled with logit-link functions, where the response variable was implemented as the ratio between the number of events (e.g. number of vital tips) and the number of trials (e.g. number of observed tips). Element concentration, number of morphotypes, densities of root tips and ramifications (i.e. tips and ramifications per unit of rootlet length) were compared with generalised linear models (GLMs). Data for ramifications were $\log$ transformed to respect the assumption of normality in data distribution. Overall tests for the significance of the fixed effects based on factorial comparisons were evaluated with type III hypotheses.

The morphotypes were used in a multivariate analysis to investigate the effect of the treatments on the most frequent ECM. Canonical discriminant analysis was applied separately for each site to find linear combinations of quantitative variables, represented by the frequencies of the morphotypes, which provide maximal separation between treatments, and successively test the hypothesis that the class means are equal in the population. The morphotypes were grouped by soil sample, with a resulting $n$ of 36, and included in the analysis only if observed in at least three different samples. Wilks' $\lambda$ was performed for overall comparison of the class means.

\section{Results}

\subsection{Effects of treatments on soil conditions}

Different absolute values but similar temporal patterns of soil temperature were observed at both sites. In winter, the temperature was close to $0{ }^{\circ} \mathrm{C}$ (Fig. 2). In spring, complete snowmelt was followed by an abrupt increase in soil temperature. The pattern of soil temperatures in summer and early autumn followed that of the air temperature, but with lower daily and seasonal variations (data not shown). Heating started in April, usually with a 2-week delay between SIM and BER to reflect the difference in air temperature and timing of snowmelt between the two sites. For the three studied years, the system successfully maintained the defined temperature differential of $4{ }^{\circ} \mathrm{C}$ until July, simulating years with earlier snow melts and consequently longer snow-free periods in early spring.

$\mathrm{C}_{\text {tot }}$ in the organic horizon varied between 375.0 and $483.0 \mathrm{~g} \mathrm{~kg}^{-1}$, while $\mathrm{N}_{\text {tot }}$ ranged between 8 and $9.7 \mathrm{~g} \mathrm{~kg}^{-1}$ (Table 2). On average, the soil around $\mathrm{N}$ trees showed higher concentrations of $\mathrm{N}_{\text {tot }}$ in both sites. However, no significant effect of the treatments was observed on soil chemistry $(p>0.05)$, except for $\mathrm{S}$ in BER, where significantly lower concentrations were detected in the soil of $\mathrm{H}$ trees $(p<0.05)$. The two sites differed in terms of soil chemistry, with BER showing higher concentrations of $\mathrm{C}_{\mathrm{tot}}, \mathrm{Ca}, \mathrm{Mg}$ and $\mathrm{Fe}$. These 


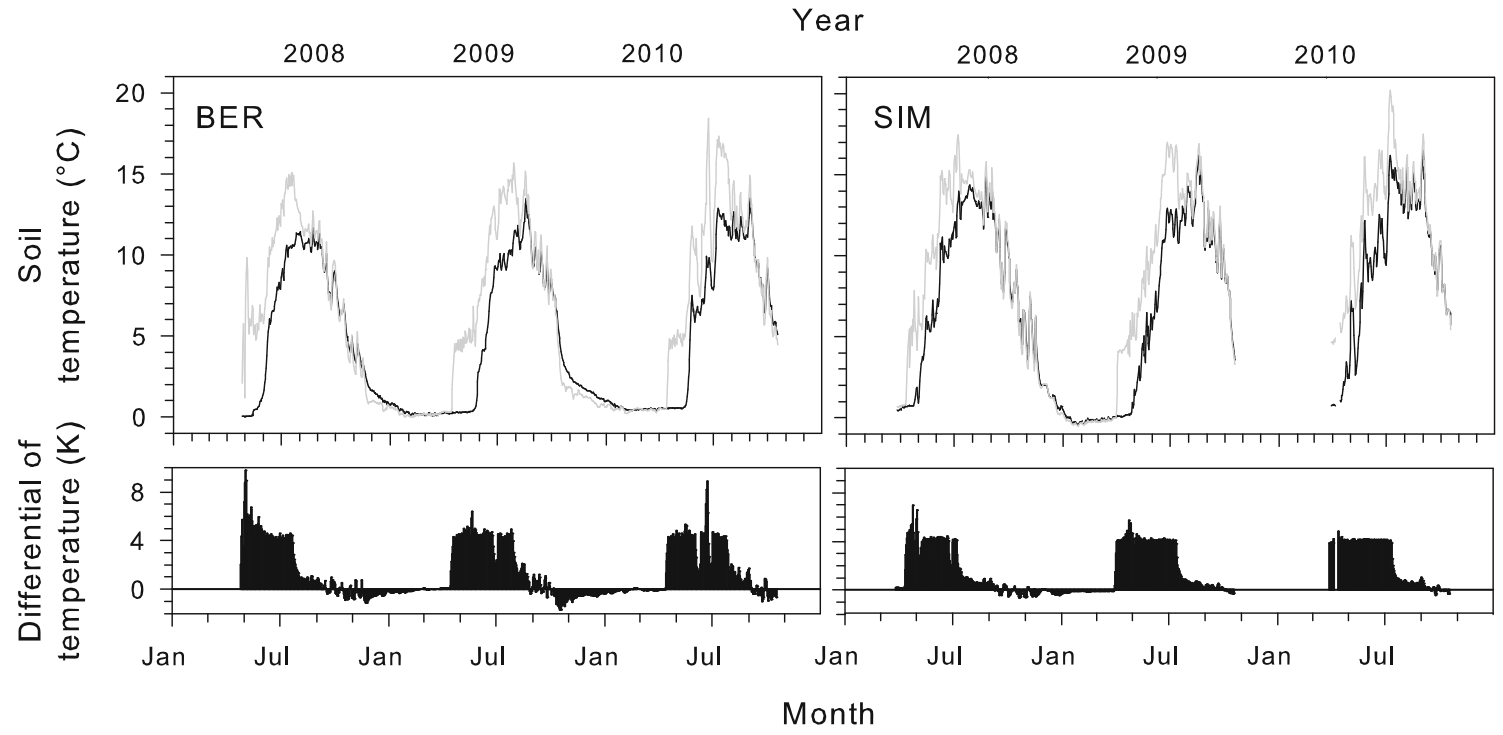

Fig. 2 Soil temperature in control (black line) and heated (gray line) trees and relative differential in BER and SIM during the 3 years of experiment

differences were confirmed both for all trees and $\mathrm{C}$ trees only. However, mean $\mathrm{pH}$ was higher in SIM, but this was not confirmed in $\mathrm{C}$ trees.

\subsection{Root tips and ECM}

In BER and SIM, vital root tips represented 94.0 and $90.5 \%$ of the roots analysed, respectively (Fig. 3). A significant effect of the treatments was observed in BER, where greater proportions of vital root tips were detected for $\mathrm{H}$ trees $(p<0.05$, Table 3), but no differences were found for $\mathrm{N}$ trees. Differences among treatments were not significant in $\operatorname{SIM}(p>0.05$, Table 3). Overall, $89.1 \%$ of the root tips showed ECM, but wide differences were observed among treatments, mainly in $\mathrm{H}$ trees (Fig. 3). $\mathrm{H}$ treatment significantly reduced the proportion of ECM in BER, with 83.1 and $91.3 \%$ of ECM detected in heated and non-heated trees, respectively $(p<0.0001$, Table 3). Although a small difference was observed in SIM with 90.0 vs. $92.0 \%$ of ECM in heated and non-heated trees, respectively, no significant difference was detected ( $p>0.05$, Table 3$)$. No effect was observed for the combined treatment $\mathrm{N} \times \mathrm{H}(p>0.05)$. Compared to SIM, C trees in BER had greater proportions of vital root tips $(91.1 \mathrm{vs.}$ $92.8 \%$ ), but similar proportions of ECM (92.3 vs. $92.1 \%$ ).

The analysed fragments had a length ranging between 0.2 and $2.3 \mathrm{~cm}$. On average, 9.0 tips $\mathrm{cm}^{-1}$ were present, with root tips being slightly more abundant in BER. In BER, $H$ trees showed fewer tips per centimetre of root than non-heated trees, but differences were not significant $(p>0.05$, Table 3). Similarly, no effect of the treatments
Table $2 \mathrm{C}$ and $\mathrm{N}$ content and exchangeable cations of the organic horizon measured after 3 years of treatment

$C$ control, $H$ heated, $N \mathrm{~N}$ enriched, $\mathrm{NH}$ combined treatment

\begin{tabular}{|c|c|c|c|c|c|c|c|c|}
\hline & \multicolumn{4}{|l|}{ BER } & \multicolumn{4}{|l|}{ SIM } \\
\hline & $\mathrm{C}$ & $\mathrm{N}$ & $\mathrm{H}$ & NH & $\mathrm{C}$ & $\mathrm{N}$ & $\mathrm{H}$ & $\mathrm{NH}$ \\
\hline $\mathrm{C}_{\text {tot }}\left(\mathrm{g} \mathrm{kg}^{-1}\right)$ & 428.3 & 483.0 & 454.7 & 462.0 & 375.0 & 426.0 & 426.0 & 387.7 \\
\hline $\mathrm{N}_{\text {tot }}\left(\mathrm{g} \mathrm{kg}^{-1}\right)$ & 8.5 & 8.9 & 8.0 & 8.7 & 9.7 & 10.9 & 11.1 & 10.3 \\
\hline $\mathrm{K}\left(\mathrm{mg} \mathrm{kg}^{-1}\right)$ & 471.0 & 401.7 & 504.3 & 505.7 & 552.0 & 410.3 & 523.7 & 529.7 \\
\hline $\mathrm{Ca}\left(\mathrm{mg} \mathrm{kg}^{-1}\right)$ & $2,636.7$ & $2,920.0$ & $2,260.0$ & $2,030.0$ & $1,893.3$ & $1,503.3$ & $1,830.0$ & $1,346.7$ \\
\hline $\operatorname{Mg}\left(\mathrm{mg} \mathrm{kg}^{-1}\right)$ & 444.0 & 356.7 & 366.3 & 402.3 & 332.0 & 276.7 & 282.3 & 328.0 \\
\hline $\mathrm{Mn}\left(\mathrm{mg} \mathrm{kg}^{-1}\right)$ & 78.1 & 43.0 & 102.4 & 63.9 & 142.8 & 124.3 & 131.0 & 129.7 \\
\hline $\mathrm{Al}\left(\mathrm{mg} \mathrm{kg}^{-1}\right)$ & 245.7 & 297.3 & 398.7 & 393.0 & 254.0 & 727.7 & 504.3 & 508.0 \\
\hline $\mathrm{Fe}\left(\mathrm{mg} \mathrm{kg}^{-1}\right)$ & 450.3 & 306.3 & 735.3 & 370.7 & 287.0 & 409.7 & 395.3 & 608.0 \\
\hline $\mathrm{Na}\left(\mathrm{mg} \mathrm{kg}^{-1}\right)$ & 24.7 & 25.3 & 24.0 & 26.7 & 29.7 & 31.3 & 33.0 & 30.3 \\
\hline $\mathrm{S}\left(\mathrm{mg} \mathrm{kg}^{-1}\right)$ & 91.3 & 83.3 & 70.7 & 72.7 & 103.3 & 106.7 & 123.7 & 103.3 \\
\hline $\mathrm{pH}$ & 2.9 & 2.6 & 2.7 & 2.6 & 2.8 & 3.1 & 3.1 & 3.1 \\
\hline
\end{tabular}


Fig. 3 Proportion of vital and ECM root tips and number of morphotypes per soil core recorded on black spruce in BER and SIM after 3 years of treatment reported as mean \pm standard error. $C$ control, $H$ heated, $N \mathrm{~N}$ enriched, $\mathrm{NH}$ combined treatment
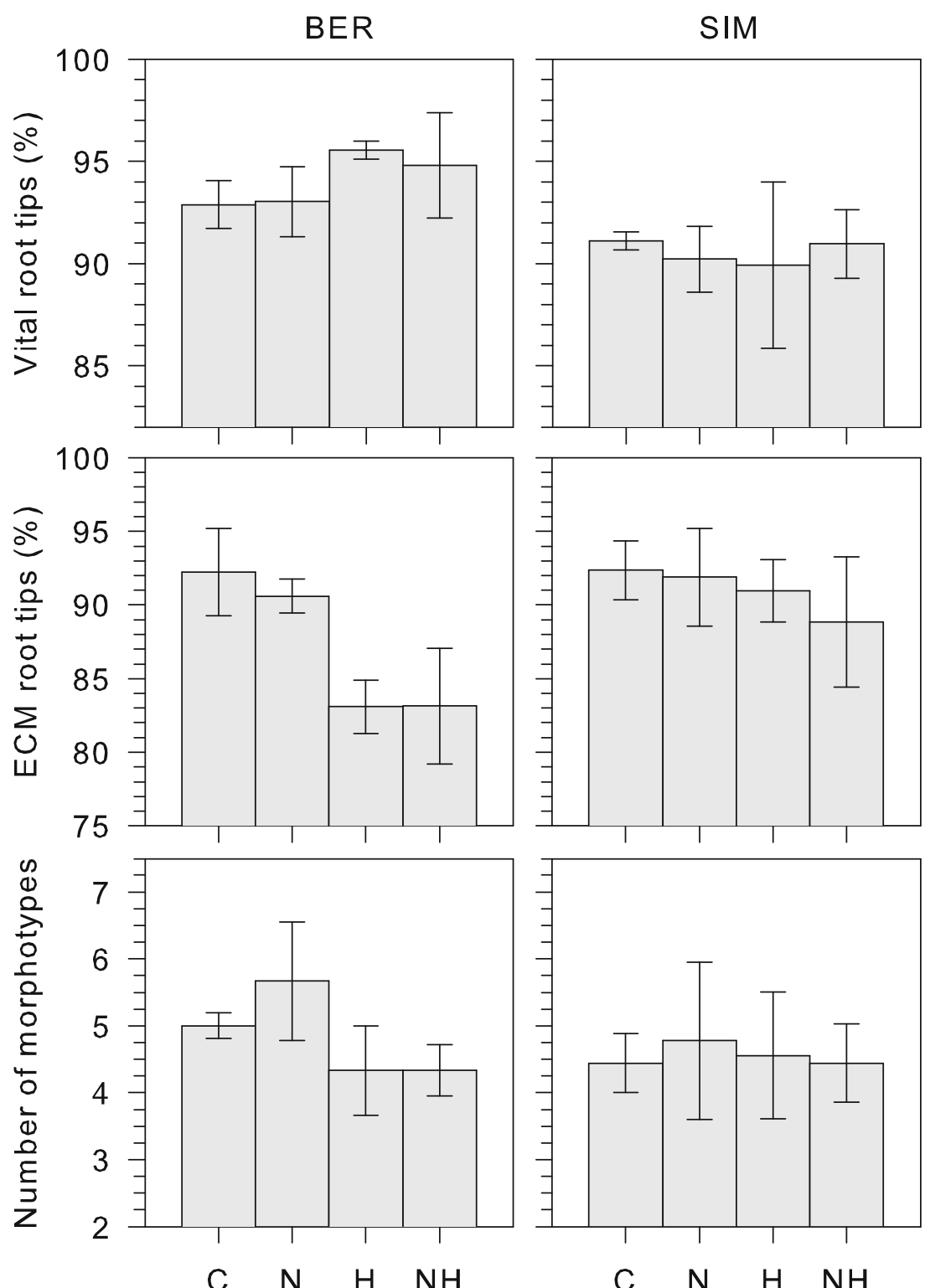

Treatment

was detected in the number of ramifications per centimeter of root $(p>0.05$, Table 3$)$. On average, 0.5 ramifications $\mathrm{cm}^{-1}$ were calculated, with $\mathrm{C}$ trees in SIM exhibiting the highest density of ramifications.

\subsection{Morphotypes}

A total of 41 morphotypes were detected in the plots, consisting of a few dominant fungal species and many that
Table $3 F$ values resulting from the type III tests of fixed effects for GLMM and GLM models, where $\mathrm{H}$ and $\mathrm{N}$ correspond to the heating and $\mathrm{N}$ enrichment treatments

${ }^{*} p<0.05,{ }^{* *} p<0.0001$, statistically significant differences

\begin{tabular}{|c|c|c|c|c|c|c|}
\hline & \multicolumn{3}{|l|}{ BER } & \multicolumn{3}{|l|}{ SIM } \\
\hline & $\mathrm{N}$ & $\mathrm{H}$ & $\mathrm{N} \times \mathrm{H}$ & $\mathrm{N}$ & $\mathrm{H}$ & $\mathrm{N} \times \mathrm{H}$ \\
\hline Vital root tips & 0.18 & $5.98 *$ & 0.31 & 0.00 & 0.04 & 0.73 \\
\hline ECM root tips & 0.56 & $37.37 * *$ & 0.73 & 1.26 & 3.02 & 0.33 \\
\hline Density of root tips & 0.79 & 1.72 & 0.31 & 0.55 & 0.32 & 0.16 \\
\hline Density of ramifications & 0.05 & 3.18 & 1.59 & 0.08 & 1.20 & 0.44 \\
\hline Number of morphotypes & 0.31 & 2.82 & 0.31 & 0.03 & 0.03 & 0.11 \\
\hline
\end{tabular}


Table 4 Relative frequency (percent) of the 41 morphotypes detected on black spruce in BER and SIM after 3 years of treatment
The characteristics of each morphotype are reported in the Supplementary material

$C$ control, $H$ heated, $N \mathrm{~N}$ enriched, $\mathrm{NH}$ combined treatment

${ }^{a}$ Morphotypes included in the canonical discriminant analysis

\begin{tabular}{|c|c|c|c|c|c|c|c|c|c|c|}
\hline \multirow[b]{2}{*}{ Ectomycorrhizal morphotype } & \multicolumn{5}{|l|}{ BER } & \multicolumn{5}{|l|}{ SIM } \\
\hline & $\mathrm{C}$ & $\mathrm{N}$ & $\mathrm{H}$ & $\mathrm{NH}$ & & $\mathrm{C}$ & $\mathrm{N}$ & $\mathrm{H}$ & $\mathrm{NH}$ & \\
\hline Cenococcum geophilum & 18.7 & 23.7 & 20.7 & 23.8 & $-^{\mathrm{a}}$ & 31.3 & 29.7 & 17.2 & 26.2 & $-^{\mathrm{a}}$ \\
\hline Hebeloma sp. & 21.1 & 27.4 & 8.8 & 15.9 & ${ }^{\mathrm{a}}$ & 7.2 & 3.2 & 8.7 & 1.3 & ${ }^{\mathrm{a}}$ \\
\hline Unknown fungus I & 1.6 & 0.9 & 0.9 & 0 & ${ }^{\mathrm{a}}$ & 14.1 & 0.5 & 9.2 & 5.5 & ${ }^{\mathrm{a}}$ \\
\hline Piceirhiza bicolorata & 1.2 & 0 & 0.4 & 3.4 & $-^{\mathrm{a}}$ & 0.4 & 3 & 0.5 & 0.9 & $-^{\mathrm{a}}$ \\
\hline Unknown fungus II & 0.3 & 4.4 & 9.9 & 2.3 & $-^{\mathrm{a}}$ & 3.5 & 7.3 & 0 & 22 & $-^{\mathrm{a}}$ \\
\hline Unknown fungus III & 3.8 & 6.5 & 2.2 & 5.1 & ${ }^{\mathrm{a}}$ & 3.2 & 0 & 2.9 & 3.1 & ${ }^{\mathrm{a}}$ \\
\hline Cortinariaceae I & 0 & 1.8 & 1.1 & 0.2 & ${ }^{\mathrm{a}}$ & 4.6 & 3.2 & 4.2 & 0.9 & ${ }^{\mathrm{a}}$ \\
\hline Lactarius sp. I & 0 & 6.5 & 8.8 & 21.6 & ${ }^{\mathrm{a}}$ & 8.6 & 5.5 & 9.4 & 11.7 & ${ }^{\mathrm{a}}$ \\
\hline Tricholomataceae & 6.2 & 0.9 & 0.6 & 0 & ${ }^{\mathrm{a}}$ & 0 & 6.6 & 12.3 & 1.5 & ${ }^{\mathrm{a}}$ \\
\hline Mycelium radicis atrovirens & 1.6 & 2.5 & 0 & 3.4 & $-^{\mathrm{a}}$ & 0.7 & 0 & 0.2 & 0.7 & $-^{\mathrm{a}}$ \\
\hline Piloderma fallax & 0 & 1.2 & 0.4 & 0 & $-^{\mathrm{a}}$ & 5.5 & 5.5 & 7.1 & 13.2 & $-^{\mathrm{a}}$ \\
\hline Cortinariaceae II & 2.2 & 3.5 & 14.7 & 8.6 & $-^{\mathrm{a}}$ & 0 & 0.2 & 0 & 0.4 & $-^{\mathrm{a}}$ \\
\hline Unknown fungus IV & 5.4 & 1.1 & 0 & 0.4 & $-^{\mathrm{a}}$ & 0.9 & 7.7 & 2 & 0 & $-^{\mathrm{a}}$ \\
\hline Inocybe sp. & 5.9 & 0.9 & 0 & 0 & ${ }^{\mathrm{a}}$ & 4 & 0.7 & 1.1 & 0 & ${ }^{\mathrm{a}}$ \\
\hline Unknown fungus $\mathrm{V}$ & 2.8 & 1.6 & 0 & 0 & ${ }^{\mathrm{a}}$ & 3.7 & 0 & 5.8 & 1.8 & ${ }^{\mathrm{a}}$ \\
\hline Cortinarius sp. & 0 & 0 & 3.9 & 2.3 & ${ }^{\mathrm{a}}$ & 0 & 5.2 & 1.8 & 9 & ${ }^{\mathrm{a}}$ \\
\hline Russula sp. I & 0 & 0 & 0 & 6.8 & $-^{\mathrm{a}}$ & 1.2 & 4.1 & 0.5 & 0 & $-^{\mathrm{a}}$ \\
\hline Unknown fungus VI & 1.6 & 3.5 & 0 & 2.4 & ${ }^{\mathrm{a}}$ & 0.7 & 0 & 0 & 0.4 & ${ }^{\mathrm{a}}$ \\
\hline Amphinema byssoides & 0.5 & 1.9 & 0 & 1.9 & ${ }^{\mathrm{a}}$ & 0 & 0 & 4.2 & 0 & ${ }^{\mathrm{a}}$ \\
\hline Neocudoniella radicella & 0 & 0 & 0.7 & 0 & ${ }^{\mathrm{a}}$ & 0.2 & 0.9 & 0 & 0 & ${ }^{\mathrm{a}}$ \\
\hline Unknown fungus VII & 0 & 1.8 & 6.3 & 0 & $-^{\mathrm{a}}$ & 0 & 0 & 0 & 0.2 & $-^{\mathrm{a}}$ \\
\hline Piceirhiza gelatinosa & 8.3 & 0.4 & 0 & 0.4 & $-^{\mathrm{a}}$ & 0 & 0 & 0 & 0 & \\
\hline Unknown fungus VIII & 0 & 0 & 0 & 0 & & 0.5 & 0.9 & 6.1 & 0 & $-^{\mathrm{a}}$ \\
\hline Unknown fungus IX & 0.7 & 1.4 & 0 & 0 & $-^{\mathrm{a}}$ & 0 & 0 & 0.9 & 0 & $-^{\mathrm{a}}$ \\
\hline Unknown fungus $\mathrm{X}$ & 0 & 0 & 0 & 0 & & 9.5 & 3.2 & 0 & 0.7 & $-^{\mathrm{a}}$ \\
\hline Unknown fungus XI & 11.2 & 1.8 & 1.3 & 0 & ${ }^{\mathrm{a}}$ & 0 & 0 & 0 & 0 & \\
\hline Unknown fungus XII & 3.5 & 0.2 & 0 & 0 & $-^{\mathrm{a}}$ & 0 & 0 & 0 & 0 & \\
\hline Paxillus involutus & 0 & 0 & 0 & 0 & & 0 & 0.4 & 0.9 & 0 & \\
\hline Sebacinaceae I & 0.2 & 0.7 & 0 & 0 & & 0 & 0 & 0 & 0 & \\
\hline Sebacinaceae II & 0 & 0 & 0 & 0 & & 0 & 0 & 0.2 & 0.5 & \\
\hline Unknown fungus XIII & 0 & 0 & 0 & 0 & & 0.2 & 0 & 2.2 & 0 & $-^{\mathrm{a}}$ \\
\hline Russula sp. II & 0 & 0 & 9.5 & 1.7 & & 0 & 0 & 0 & 0 & \\
\hline Russulaceae & 0 & 0 & 0 & 0 & & 0 & 11.8 & 0 & 0 & \\
\hline Unknown fungus XIV & 0 & 5.6 & 0 & 0 & & 0 & 0 & 0 & 0 & \\
\hline Unknown fungus XV & 0.7 & 0 & 0 & 0 & & 0 & 0 & 0 & 0 & \\
\hline Hydnellum sp. & 0.9 & 0 & 0 & 0 & & 0 & 0 & 0 & 0 & \\
\hline Unknown fungus XVI & 0 & 0 & 7.6 & 0 & & 0 & 0 & 0 & 0 & \\
\hline Tomentella $\mathrm{sp}$. & 0 & 0 & 0 & 0 & & 0 & 0.2 & 0 & 0 & \\
\hline Unknown fungus XVII & 0 & 0 & 0 & 0 & & 0 & 0 & 2.7 & 0 & \\
\hline Russula sp. III & 1.7 & 0 & 0 & 0 & & 0 & 0 & 0 & 0 & \\
\hline Lactarius sp. II & 0 & 0 & 2.1 & 0 & & 0 & 0 & 0 & 0 & \\
\hline
\end{tabular}

were observed occasionally (Table 4 and Supplementary material). Although the selected morphological and anatomical characteristics allowed most morphotypes to be associated to a species, genus, or family, 17 morphotypes remained unidentified. Cenococcum geophilum was the most frequent morphotype, with relative frequency ranging between 17.2 and $31.3 \%$. Most of the more frequent morphotypes, which belonged to the families of Cortinariaceae, Tricholomataceae and Atheliaceae, occurred in both sites, but only two $(C$. geophilum and Hebeloma sp.) were detected in all treatments 
(Table 4). Nine morphotypes were observed in only one group belonging to the control or treatment.

A wide variation in the number of morphotypes was observed among samples in all treatments and at the two sites, which ranged between one and nine morphotypes per soil core (Fig. 3). On average, 4.7 morphotypes per soil core were identified in C plots. Overall, more morphotypes were detected in $\mathrm{N}$ trees (5.2 morphotypes per soil core). Moreover, fewer morphotypes seemed to be observed in $\mathrm{H}$ and $\mathrm{NH}$ trees of BER. However, no significant effect of the treatments was detected on the richness of morphotypes in either site $(p>0.05$, Table 3$)$.

Twenty-five morphotypes from each site were used in the canonical discriminant analysis (Table 4). Overall, canonical axis 1 represented between 0.45 and 0.60 of the variation accounted for, while a lower variation of $0.27-0.29$ was explained by canonical axis 2 (Fig. 4). No discrimination was observed along canonical axis 3 (data not shown). In BER, three centroids were generated by the discriminant analysis, with control and $\mathrm{H}$ treatment being visibly separated by $\mathrm{N}$ and $\mathrm{NH}$ according to both canonical axes. A separation among centroids was also observed in SIM, with axis 2 discriminating between $\mathrm{N}$ trees and the other treatments. However, the wide variation among samples in both sites produced low values of Wilks' $\lambda$, which corresponded with non-significant $F$ statistics $(p>0.05)$, meaning that no difference was detected between the control and the three treatments. Consequently, no effect of soil heating and nitrogen addition by simulated rain was observed on the overall occurrence of the most frequent morphotypes.

\section{Discussion}

In this study, trees of mature black spruce stands were subjected to the warmer soil temperatures and increased $\mathrm{N}$ depositions expected in the next future in the boreal forest of eastern Canada in order to investigate the short-term effects on ECM. The treatment of increased $\mathrm{N}$ deposition was unable to modify the concentration of $\mathrm{N}$ in the soil and, consequently, no significant effect was observed on root vitality and ECM presence. Soil warming markedly modified the proportions of vital root tips and ECM in one site, but no effect was observed for the combined treatment $\mathrm{N} \times \mathrm{H}$. Thus, these results only partially confirm the initial hypothesis that the treatments would rapidly alter root vitality and mycorrhization.

The significant reduction in ECM root tips exhibited in the heated treatment of BER contrasted with the results observed by Clemmensen et al. (2006), which reported modified allocations of resources towards aboveground biomass at the expense of fine root biomass and increased ECM colonisation of fine roots. It was suggested that warming may enhance the growth of ECM fungi by altering the physiology of their host trees with an increase of autotrophic tissues and an enhancement of photosynthesis, which should allow more $\mathrm{C}$ to be allocated to symbionts (Deslippe et al. 2011). However, the heating treatments used by Clemmensen et al. (2006) consisted of small greenhouses constructed above the tundra vegetation for warming both surface soil and air temperature in the immediate vicinity of plants. On the contrary, the treatment applied in this study disentangled the air temperature, which remained unmodified, from that of soil, thus affecting only the belowground processes and the phenology of roots. No effect was either expected on the photosynthetic processes in the canopy of tall trees or observed on stem growth (Lupi et al. 2012a, 2012b). Moreover, the organisms monitored by Clemmensen et al. (2006) consisted of herbaceous plants and little shrubs, which could be assumed to show different metabolic rates and faster responses to environmental changes than larger trees. The presented experiment simulated the effects of a future climate change, although increases in soil temperature that are not complemented with air warming can only partially represent a natural phenomenon. This problem will persist until the technical challenges related to warming adult trees in remote fields will not be definitely resolved.

The higher proportion of vital non-colonised root tips of $\mathrm{H}$ trees could be the result of a disproportionate growth between plant and fungi, with the root system being more affected than ECM mycelium by the warmer spring temperatures. Besides, the warmer conditions favourable for root growth could have reduced the mortality of non-mycorrhizal root tips, thus increasing their lifespan and proportion relative to the total amount of root tips. BER is located at higher altitude and latitude, experiencing shorter snow-free periods and growing seasons, and with wetter and colder soils than SIM (Rossi et al. 2011b). Consequently, temperature in BER is a more critical factor for the growth of plants and fungi, which might be more sensitive to warming. This could explain why significant results were detected only in heated trees in BER, although similar trends of root tip vitality and ECM colonisation were also observed in SIM. Water is not a limiting factor in the region, where precipitations are generally frequent and homogeneously distributed during the growing season (Rossi et al. 2011a; Belien et al. 2012). Also, part of the water lost by the warmer temperatures in the soil was compensated by the water supplied by the artificial rain. Thus, the effects of heating on soil moisture for fungal growth could be considered minor or negligible.

In this experiment, $\mathrm{N}$ addition was realized by simulating a natural rainfall, with small amounts of $\mathrm{N}$ added frequently over the growing season by sprinklers installed above each experimental tree. Just like natural precipitation on $\mathrm{N}$-limited stands, a significant part of the $\mathrm{N}$ added was probably intercepted by canopy, stem and epiphytes such as lichens and mosses (Gundale et al. 2011), and only a residual 
Fig. 4 Canonical discriminant analysis of the most frequent morphotypes identified in root tips of black spruce in BER and SIM after 3 years of treatment. $C$ control, $H$ heated, $N \mathrm{~N}$ enriched, $\mathrm{NH}$ combined treatment

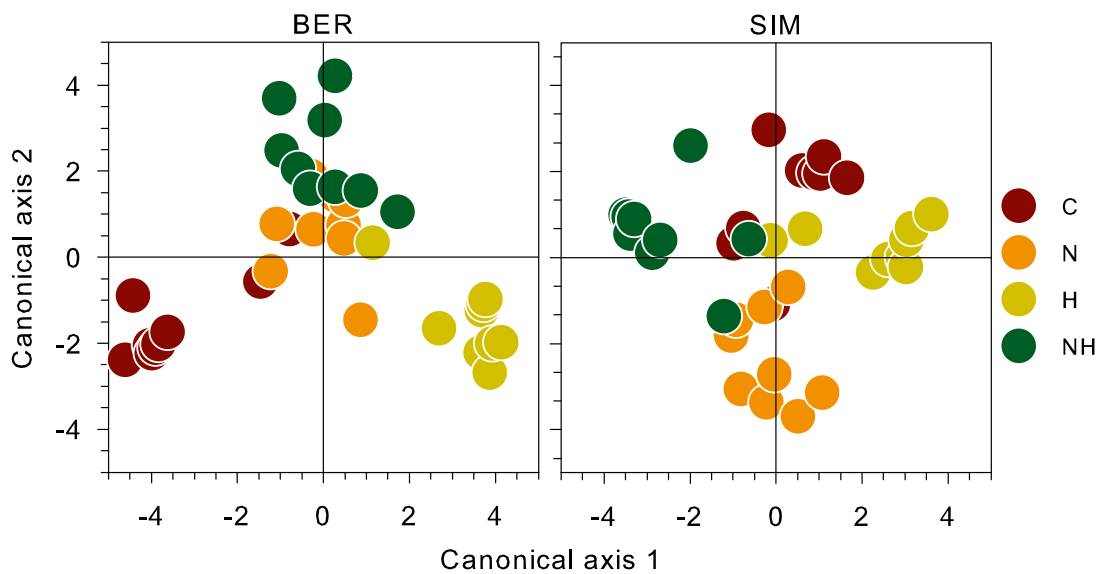

part reached the soil. Indeed, a ${ }^{15} \mathrm{~N}$ tracer experiment $\left({ }^{15} \mathrm{NH}_{4}-{ }^{15} \mathrm{NO}_{3}\right.$, at a $98 \%$ purity) realised in similar experimental conditions in a balsam fir stand in the boreal forest of Quebec has shown that aboveground vegetation is retaining 64 to $71 \%$ of the recovered tracer as compared to $29-35 \%$ for the soil (Gélinas-Pouliot 2013). The amount of $\mathrm{N}$ that reached the soils was probably readily immobilized within the large organic $\mathrm{N}$ pool with limited or inexistent effects on soil $\mathrm{N}$ concentration and $\mathrm{N}$ availability in the short term (David et al. 1998; D'Orangeville et al. 2013). Based on these results, the low amount of added $\mathrm{N}$ from our experiment was most probably rapidly immobilized in the canopy and in the forest floor organic $\mathrm{N}$ pool. Although this may have potentially affected the symbionts through an impact on the host tree, the impact on the ECM has been observed to be inexistent or undetectable.

Black spruce shows a rich mosaic of ECM associations, allowing a shift in its fungal partners according to the local conditions and to accommodate a range of climatic situations, which also explains the tolerance to edaphic extremes and the wide distribution of this species across the continent (Robertson et al. 2006). In this experiment, neither of the two treatments affected the richness of morphotypes and the proportion of the most frequent ECM, and non-significant differences were observed after 3 years of treatment on the overall occurrence of the most frequent morphotypes. In total, 30 and 33 morphotypes were characterized in the two studied sites, some of them being largely predominant among the ECM, and the majority being very infrequent or occasional. A similar species amount was reported previously in other black spruce stands (Robertson et al. 2006, Rossi et al. 2012), while a wider variability in the number of species was observed by Bruns (1995), who identified between 13 and 35 species from fruit bodies on very young stands or plantations. It is well known that DNA sequencing is the best way for taxa identification, although this technique still shows some levels of inefficiency (Tóth and Barta 2010). The less expensive morphotyping permits a significantly large amount of root tips to be sampled and observed, but can occasionally generate lumping or splitting of taxa, and data produced by this method should be used with caution (Robertson et al. 2006). This study aimed to compare the effects of different treatments with data collected with the same procedure from control plots. Thus, the eventual systematic error allowed the results to be suitably interpreted in a relative point of view (e.g. by comparing treatments), even if not necessarily according to their absolute value.

\section{Conclusions}

This study tested the hypothesis that warmer soil temperatures and increased $\mathrm{N}$ depositions can modify root vitality and mycorrhization in the short term. No effect of $\mathrm{N}$ enrichment was observed on the soil chemistry and on the overall occurrence of morphotypes at both sites. Soil warming significantly modified the proportions of vital root tips and ECM in the colder stand, where temperature was more limiting. The initial hypothesis was thus only partially validated for soil warming. $\mathrm{N}$ concentration in the soil organic layer was insensitive to short-term increases in $\mathrm{N}$ concentration of rain. Boreal soils contain large amount of $\mathrm{N}$ sequestered in recalcitrant form of organic matter, which ECM may have access to, and thus, the relatively low amount of inorganic $\mathrm{N}$ added in the short term was unable to substantially modify the growth conditions of roots and ECM. The effects on root vitality and mycorrhization from the experiment lasting 3 years and investigating the short-term responses to warmer soil temperatures and increased $\mathrm{N}$ depositions remained inconclusive.

Acknowledgments The authors thank J. Allaire, C. Boivin, M.-J. Deschênes, F. Gionest, I. Grenon, D. Laprise, C. Lupi, P. Nadeau, G. Savard, M. Thibeault-Martel and A. Turcotte for technical support, J. A. Fortin and Y. Piché for their suggestions on sampling design and A. Garside for checking the English text.

Funding This work was supported by the Natural Sciences and Engineering Research Council of Canada and Le Fond Vert du Ministère du 
Développement Durable, Environement, et Parc du Québec within the framework of the Action Plan 2006-2012 on climate change.

\section{References}

Agerer R (1991) Characterization of ectomycorrhizae. In: Norris JR, Read DJ, Varma AK (eds) Techniques for the study of mycorrhiza, vol 23, Academic. London, UK, pp 25-73

Agerer R, Rambold G (2004-2011) DEEMY - an information system for characterization and determination of ectomycorrhizae [first posted on 1 June 2004, most recent update 10 January 2011]. Available from www.deemy.de (München, Germany). Accessed October 2012

Belien E, Rossi S, Morin H, Deslauriers A (2012) Xylogenesis in black spruce subjected to a rain exclusion in the field. Can J For Res 42: $1306-1315$

Boulouf Lugo J, Deslauriers A, Rossi S (2012) Duration of xylogenesis in black spruce lengthened between 1950 and 2010. Ann Bot 110: 1099-1108

Bruns TD (1995) Thoughts on the processes that maintain local species diversity of ectomycorrhizal fungi. Plant Soil 170:63-73

Campbell JL, Rustad LE, Boyer EW, Christopher SF, Driscoll CT, Fernandez IJ, Groffman PM, Houle D, Kiekbusch J, Magill AH, Mitchell MJ, Ollinger SV (2009) Consequences of climate change for biogeochemical cycling in forests of northeastern North America. Can J For Res 39:264-284

Clemmensen KE, Michelsen A, Jonasson S, Shaver GR (2006) Increased ectomycorrhizal fungal abundance after long-term fertilization and warming of two arctic tundra ecosystems. New Phytol 171:391-404

D’Orangeville L, Houle D, Côté B, Duchesne L, Morin H (2013) Three years of increased soil temperature and atmospheric $\mathrm{N}$ deposition have no effect on the $\mathrm{N}$ status and growth of a mature balsam fir forest. Biogeosciences 10:4627-4639

David MB, Cupples AM, Lawrence GB, Shi G, Vogt K, Wargo PM (1998) Effect of chronic nitrogen additions on soil nitrogen fractions in red spruce stands. Water Air Soil Pollut 105:183-192

Deslippe JR, Hartmann M, Mohn WW, Simard SW (2011) Long-term experimental manipulation of climate alters the ectomycorrhizal community of Betula nana in Arctic tundra. Global Change Biol 17:1625-1636

Domisch T, Finér L, Lehto T, Smolander A (2002) Effect of soil temperature on nutrient allocation and mycorrhizas in Scots pine seedlings. Plant Soil 239:173-185

Duchesne L, Houle D (2008) Investigating the impact of nutrient cation removal through harvesting on the long term sustainability of the boreal forest. Ecol Appl 18:1642-1651

Gélinas-Pouliot M (2013) The fate of ${ }^{15} \mathrm{~N}$-labeled ammonium nitrate applied on trees canopy in a mature balsam-fir stand, Québec. Master thesis, Université du Québec à Chicoutimi

Goodman DM, Durall DM, Trofymow JA, Berch SM (eds) (1996) A manual of concise descriptions of North American ectomycorrhizae. Mycologue, Sidney

Gundale MJ, Deluca TH, Nordin A (2011) Bryophytes attenuate anthropogenic nitrogen inputs in boreal forests. Global Change Biol 17: 2743-2753

Houle D, Bouffard A, Duchesne L, Logan T, Harvey R (2012) Projections of future soil temperature and water content for three southern Quebec forested sites. J Clim 25:7690-7701
Kasischke ES (2000) Boreal ecosystems in the global carbon cycle. In: Kasischke ES, Stocks BJ (eds) Fire, climate change, and carbon cycling in the boreal forest. Springer, New York

Kranabetter JM, Durall DM, MacKenzie WH (2009) Diversity and species distribution of ectomycorrhizal fungi along productivity gradients of a southern boreal forest. Mycorrhiza 19:99-111

Lilleskov EA, Bruns TD, Horton TR, Taylor DL, Grogan P (2004) Detection of forest stand-level spatial structure in ectomycorrhizal fungal communities. FEMS Microbiol Ecol 49:319-332

Lilleskov EA, Wargo PM, Vogt KA, Vogt DJ (2008) Mycorrhizal fungal community relationship to root nitrogen concentration over a regional atmospheric nitrogen deposition gradient in the northeastern USA. Can J For Res 38:1260-1266

Lupi C, Morin H, Deslauriers A, Rossi S (2010) Xylem phenology and wood production: resolving the chicken-or-egg dilemma. Plant Cell Environ 33:1721-1730

Lupi C, Morin H, Deslauriers A, Rossi S (2012a) Xylogenesis in black spruce: does soil temperature matter? Tree Physiol 32:74-82

Lupi C, Morin H, Deslauriers A, Rossi S, Houle D (2012b) Increasing nitrogen availability and soil temperature: effects on xylem phenology and anatomy of mature black spruce. Can J For Res 42:1277-1288

Mehmann B, Egli S, Braus GH, Brunner I (1995) Coincidence between molecularly or morphologically classified ectomycorrhizal morphotypes and fruitbodies in a spruce forest. In: Stocchi V, Bonfante P, Nuti M (eds) Biotechnology of ectomycorrhizae. Plenum, New York, pp 41-52

Montecchio L, Causin R, Rossi S, Mutto Accordi S (2004) Changes in ectomycorrhizal diversity in a declining Quercus ilex coastal forest. Phytopatologia Mediterranea 43:26-34

Plummer DA, Caya D, Frigon A, Côté H, Giguère M, Paquin D, Biner S, Harvey R, de Elia R (2006) Climate and climate change over North America as simulated by the Canadian RCM. J Clim 19:3112-3132

Read DJ, Leake JR, Perez-Moreno J (2004) Mycorrhizal fungi as drivers of ecosystem processes in heathland and boreal forest biomes. Can J Bot 82:1243-1263

Robertson SJ, Tackaberry LE, Egger KN, Massicotte HB (2006) Ectomycorrhizal fungal communities of black spruce differ between wetland and upland forests. Can J For Res 36:972-985

Rossi S, Bordeleau A, Houle D, Morin H (2012) Effect of chronic ammonium-nitrate addition on the ectomycorrhizal community in a black spruce stand. Can J For Res 42:1204-1212

Rossi S, Morin H, Deslauriers A (2011a) Multi-scale influence of snowmelt on xylogenesis of black spruce. Arct Antarct Alp Res 43:457-464

Rossi S, Morin H, Deslauriers A, Plourde P-Y (2011b) Predicting xylem phenology in black spruce under climate warming. Global Change Biol 17:614-625

Rossi S, Tremblay M-J, Morin H, Levasseur V (2009) Stand structure and dynamics of Picea mariana on the northern border of the natural closed boreal forest in Quebec, Canada. Can J For Res 39:2307-2318

Ruess RW, Hendrick RL, Burton AJ, Pregitzer KS, Sveinbjornssön B, Allen MF, Maurer GE (2003) Coupling fine root dynamics with ecosystem carbon cycling in black spruce forests of interior Alaska. Ecol Monogr 73:643-662

Staddon PL, Heinemeyer A, Fitter AH (2002) Mycorrhizas and global environmental change: research at different scales. Plant Soil 244 253-261

Thibeault-Martel M, Krause C, Morin H, Rossi S (2008) Cambial activity and intra-annual xylem formation in roots and stems of Abies balsamea and Picea mariana. Ann Bot 102:667-674

Tóth BB, Barta Z (2010) Ecological studies of ectomycorrhizal fungi: an analysis of survey methods. Fungal Divers 45:3-19 